\title{
The Status of the Librarian According to Accrediting Standards of Regional and Professional Associations
}

By FRITZ VEIT

$\mathrm{T}$ HE COLLEGE and university librarian has shown through the years a continuing and ever increasing concern with his status. This is not surprising, since not only his compensation but also his academic perquisites vary with his status.

A recent collection of articles edited by Downs ${ }^{1}$ provides considerable assistance to librarians and administrators who may be concerned with personnel matters. In his introductory statement and in his own basic contributions to this volume, Downs leaves no doubt that academic status is the goal toward which librarians should strive. ${ }^{2}$

Downs observes that librarians have not become a part of the academic community until they are fully integrated with the faculty. He writes: ". . . academic and faculty should carry the same connotation. Anything less than that leaves the librarians in a kind of limbo..."3 Most of the writers included in the volume adopt or at least approach Downs' viewpoint. A few feel strongly that faculty rank should be assigned only to those who are engaged in formal teaching. All agree that the professional academic librarian should be rewarded in pay and in esteem in accordance with his background and experience.

It would seem to be of considerable interest whether the librarians' hopes and strivings have been given support in standards issued by the regional accredit-

1 Robert B. Downs (ed.), The Status of American College and University Librarians (ACRL Monograph No. 22; Chicago: ALA, 1958).

2 Ibid., pp. 13-27, 77-85, 161-68.

2 Ibid., p. 14
Dr. Veit is Director of Libraries, Chicago Teachers College.

ing associations and the professional associations. An analysis of these standards is greatly facilitated since another recent compilation-also in the ACRL Monograph series-has become available. ${ }^{4}$ This compilation-ACRL Monograph No. 20-gathers within one volume the requirements for libraries of institutions of higher education "specified by the twenty-one professional and six regional associations recognized by the National Commission on Accrediting."5

For the purposes of our analysis we are concerned only with those portions of the provisions which relate to the library staff. We shall, however, introduce other matters if they are likely to affect the personnel policy. Silence regarding personnel on the part of a professional organization should not necessarily be interpreted as a lack of interest in staff matters. We shall note, for instance, that some professional accrediting groups are satisfied with the approval by the regional associations of the whole college or university library, including that of the professional school.

Standards may deal with library personnel in various ways: ${ }^{6}$ (1) They may

4 Eli M. Oboler, Ruth Walling, and David C. Weber (comps.), College and University Library Accreditation Standards-1957 (ACRL Monograph No. 20; Chicago: ACRL, 1958). In subsequent footnotes this reference will be cited as ACRL Monograph 20.

will be cited a

- This classification is partly patterned after the one contained in Downs, op. cit. 
require that the professional library staff be given full faculty status. (2) They may require that the professional library staff be given academic status (for the purposes of this discussion a status which gives only some but not all of the academic perquisites). (3) They may assign the staff to a special category which may be designated academic or professional. (4) They may assign the staff to a civil service or similar classified plan. (5) They may evaluate the staff in terms of desirable personal traits, academic background, professional experience, responsibilities or privileges, without specifying any status. (6) They may be silent with regard to the staff.

It should also be noted that any of these provisions may concern themselves with the whole library staff, the professional staff, or only the head librarian.

The textual presentation is supplemented by two tables. In the tables entry columns are not provided for all six categories but only for those which are represented in the various accrediting standards. Table 1 recapitulates the personnel provisions governing accreditation by the six regional associations. Similarly, Table 2 notes in succinct form personnel standards and practices applied by the twenty-one professional associations. Table 2, in addition, indicates the place the professional school library is assigned within the college or university. This information is given since it is assumed that the professional library's form of organization may have a bearing on its personnel policy. The tables should be helpful in revealing similarities and differences between the accreditation procedures of the various associations.

\section{Regional Accrediting Associations}

The Middle States Association of Colleges and Secondary Schools recognizes in its standards that for the performance of the various college functions there is a need of qualified and organized per- sonnel-among them librarians. ${ }^{7}$ The standards require close cooperation between library staff and faculty in the planning and development of the library resources. But they demand only with regard to the head librarian that "his faculty status should be commensurate with the significance of his task."

The rules governing the New England Association of Colleges and Secondary Schools $^{8}$ make a slight distinction between senior colleges and universities on one hand and other institutions of higher education granting the baccalaureate or higher degree on the other hand. Senior colleges and universities are expected to employ one or more fulltime professionally trained librarians, "and at least one should have full faculty ranking." With regard to "other institutions" the standards seem more lenient; they note that "it is desirable that one staff member should have full faculty ranking." It would seem that by adding the words "it is desirable" the assignment to faculty rank, while favored by the accrediting association, is left largely to the discretion of the employing institution.

The standards of the North Central Association of Colleges and Secondary Schools ${ }^{9}$ set forth that the staff should be both competent and under professional direction. They further note that "the librarian will normally hold academic rank as a member of the faculty." While faculty status for the head librarian is the normal expectation it need not

7 Middle States Association of Colleges and Secondary Schools, Commission on Institutions of Higher Education, Characteristics of Excellence in Higher Ed. Education, Characteristics of Excellence in Higher Ed(Document No. 3.00; The Association, 1955), pp. 3-4; Middle States Association of Colleges and Secondary Schools, Commission on Institutions of Higher Educa. tion, Suggestions on the Evaluation of Libraries for the Middle States Association (Document No. 4.80; The Association, 1953). (ACRL Monograph 20, pp. 7-9). 8 New England Association of Colleges and Secondary Schools, Minimum Requirements For An Acceptable Senior College, University or Other Institution of Higher Education Granting the Baccalaureate or Higher Degree (The Association, 1951), p. 4. (ACRL Monograph 20, p. 9).

${ }^{\circ}$ North Central Association of Colleges and Secondary Schools, Commission on Colleges and Universities, Revised Manual of Accreditation (Chicago: The Association, 1952). (ACRL Monograph 20, pp. 10-14).

COLLEGE ANDRESEARCH LIBRARIES 
necessarily be granted by colleges seeking accreditation.

In its provisions ${ }^{10}$ the Northwest Association of Secondary and Higher Schools does not concern itself specifically with rank and status of the library staff members. The rules pertinent to library accreditation expect this kind of information for each library employee: "Hours worked per week; duties; salary; academic degrees; and, special library training."

The Constitution and Standards of the Southern Association of Colleges and Secondary Schools ${ }^{11}$ gives to the whole professional library staff full faculty recognition. "In order to insure faculty-library cooperation and a high quality of library service, the librarian and other members of the professional staff should be well qualified academically, professionally, and personally, and they should have faculty rank, comparable salaries, and privileges."

The Statement of Standards of the Committee on Membership and Standards of the Western College Association $^{12}$ contains various "library criteria" which are put in the form of questions. With regard to the whole staff, questions such as the following are asked: "Do staff members have adequate vacations? Sabbatical allowance? Retirement plan in effect? Is a regular salary scale in effect?" The question as to faculty rank is raised in this way: "Are the librarian and the professional heads of library departments members of the faculty?" One may deduce from this question that the head librarian and the department heads are expected to be given

10 Northwest Association of Secondary and Higher Schools, Commission on Higher Schools, Guide for Self. Evaluation and Accreditation of Higher Schools (Rev. ed; Eugene, Ore.: 1955), pp. 9-10. (ACRL Monograph 20, pp. 13-14).

il Southern Association of Colleges and Secondary Schools, Constitution and Standards of the Southern Association of Colleges and Secondary Schools (Atlanta, Ga.: [1955?], pp. 11, 14-15. (ACRL Monograph 20, pp. 14-16).

College Association Committee on Mem Standards, Statement of Standards [1955], pp. 3, 5-6. (ACRL Monograph 20, pp. 16-17). faculty status. It would seem to this writer that questions are not imperatives. They are guideposts. By asking the question relating to the head librarian and the heads of departments, the association implies that faculty status is desirable for these two categories. But the rules refrain from insisting that this status be provided in all situations.

\section{Professional Associations}

The section dealing with the professional associations shows very great variations among its library provisions. A number of the associations point to various acceptable forms of organization, usually leaving the choice to local determination-for instance the professional library may be an integral part of the general university or college library, or it may be autonomous. The last column of Table 2 records briefly the several instances in which reference is made to the forms of organization or location of the professional library. It is worth noting such information since frequently the rules governing the general library personnel are extended to that of a professional school library only if the latter is an integral part of the general library system. Also, as has been mentioned before, a professional organization may concern itself in detail with library matters or it may adopt the library provisions contained in the standards of the regional accrediting agencies, either in full or in part.

In its Standards for Membership, ${ }^{13}$ the American Association of Collegiate Schools of Business makes no reference at all to matters of library personnel. The instruction sheet which the members of the visitation teams use for guidance likewise makes no reference to the staff. ${ }^{14}$

The standards of the American Bar

18 American Association of Collegiate Schools of Business. Standards for Membership ([St. Louis?] 1956), sec. 7. (ACRL Monograph 20, p. 17).

14 American Association of Collegiate Schools of Business, Information to be Supplied (St. Louis: The Association, n.d.), p. 3. (ACRL Monograph 20, p. 18). 
TABLE 1

Status as Determined by Regional Accrediting Association Standards

\begin{tabular}{|c|c|c|c|}
\hline \multirow[b]{2}{*}{ ASSOCIATION } & \multicolumn{2}{|c|}{ FACULTY STATUS } & \multirow{2}{*}{$\begin{array}{l}\text { STAFF CONSIDERED IN TERMS } \\
\text { OF DESIRABLE TRAITS, } \\
\text { TRAINING, EXPERIENCE, ETC. }\end{array}$} \\
\hline & Head & Others & \\
\hline Middle States Association & $\begin{array}{l}\text { Determined by } \\
\text { significance of } \\
\text { task }\end{array}$ & & $\begin{array}{l}\text { Adequacy of staff in } \\
\text { numbers, qualification, and } \\
\text { personal effectiveness }\end{array}$ \\
\hline $\begin{array}{l}\text { New England Association } \\
\text { (a) Senior colleges and } \\
\text { universities }\end{array}$ & $\begin{array}{l}\text { At least one } \\
\text { should have full } \\
\text { faculty rating }\end{array}$ & & $\begin{array}{l}\text { One or more full-time } \\
\text { professionally trained } \\
\text { librarians should be } \\
\text { employed }\end{array}$ \\
\hline $\begin{array}{l}\text { (b) Other institutions of } \\
\text { higher learning grant- } \\
\text { ing the baccalaureate } \\
\text { or higher degree }\end{array}$ & $\begin{array}{l}\text { Desirable that } \\
\text { one should have } \\
\text { full faculty rating }\end{array}$ & & $\begin{array}{l}\text { On o or more full-time } \\
\text { professionally trained } \\
\text { librarians should be } \\
\text { employed }\end{array}$ \\
\hline North Central Association & $\begin{array}{l}\text { Librarian will } \\
\text { normally hold } \\
\text { rank as a mem- } \\
\text { ber of the faculty }\end{array}$ & & $\begin{array}{l}\text { Competent and under } \\
\text { professional direction }\end{array}$ \\
\hline Northwest Association & & & $\begin{array}{l}\text { List of all members giving } \\
\text { for each duties, academic } \\
\text { degrees, and professional } \\
\text { training }\end{array}$ \\
\hline Southern Association & $\begin{array}{l}\text { Faculty rank, } \\
\text { comparable sal- } \\
\text { aries and } \\
\text { privileges }\end{array}$ & $\begin{array}{l}\text { Faculty rank, } \\
\text { comparable sal- } \\
\text { aries and } \\
\text { privileges to all } \\
\text { professional } \\
\text { staff members }\end{array}$ & $\begin{array}{l}\text { Well qualified academi- } \\
\text { cally, professionally, and } \\
\text { personally }\end{array}$ \\
\hline Western College Association & $\begin{array}{l}\text { Is the librarian } \\
\text { member of } \\
\text { faculty? }\end{array}$ & $\begin{array}{l}\text { Are professional } \\
\text { heads of library } \\
\text { departments } \\
\text { members of } \\
\text { faculty? }\end{array}$ & $\begin{array}{l}\text { List of all members, giving } \\
\text { for each educational back- } \\
\text { ground, professional } \\
\text { training, and experience }\end{array}$ \\
\hline
\end{tabular}

Association and those of the Association of American Law Schools are best treated in conjunction. The Adviser to the Section of Legal Education and Admissions to the Bar has stated that "the Council of Legal Education has never attempted to detail the library area with exactness but has preferred to leave this area largely to the American Association of Law Schools." 15

Even if the bar association ${ }^{16}$ does not

15 Letter dated September 17, 1956 to authors of ACRL Monograph No. 20. (ACRL Monograph 20, p. 19).

${ }_{10}$ American Bar Association, Section of Legal Education and Admissions to the Bar. Standards of the American Bar Association for Legal and Admissions to the Bar: Factors Bearing on the Approval of Law Schools by the American Bar Association (Chicago: The Association, 1957), pp. 7-8. (ACRL Monograph 20, pp. 18-19). spell out many details regarding the library, it recognizes the library's paramount role in legal education. Regarding personnel, the bar association standards weigh these factors: training, experience, and effectiveness of the librarian; size and training of the library staff.

The standards of the Association of American Law Schools ${ }^{17}$ are not only more detailed, but in nearly all respects they place higher demands on schools. which seek accreditation than do those of the American Bar Association. The

17 Association of American Law Schools, Proceedings of the Annual Meeting of the Association of American Law Schools, 1955, pp. 333-37. (ACRL Monograph 20, pp. 27-30).

COLLEGE ANDRESEARCH IIBRARIES 
Association of American Law Schools requires that a school have a well trained librarian who preferably is not only familiar with the practical problems of law librarianship but also has a legal education. While faculty membership is not absolutely demanded for the librarian, it is indicated as the preferred status.

Through its Committee on Professional Training the American Chemical Society has issued standards ${ }^{18}$ which are characterized by great flexibility. "Adequate library facilities" must be provided if the school attempts to comply with minimum standards. As to personnel, the standards are silent.

In a letter released by the executive secretary of the Accrediting Committee of the American Council on Education for Journalism ${ }^{19}$ it is noted that the council does not prescribe certain holdings nor concern itself with other matters of library operations. At visitations the holdings are checked with regard to pertinency to the school's objectives. No mention is made of the role of the library's personnel.

The American Council on Pharmaceutical Education stresses flexibility in the application of its standards. ${ }^{20}$ The tendency, therefore, is to state the requirements in rather broad terms. The council gives credit for outstanding characteristics of any aspect of the library organization, including personnel. With regard to staff the standards note only that the library "should be in charge of trained library personnel."

\section{The American Dental Association}

18 American Chemical Society. Committee on Professional Training. Minimum Standards Used as Criterion in Evaluating Undergraduate Professional Training in Chemistry ([Rochester, N. Y.?] The
1954 ), pp. 3-4 (ACRL Monograph 20, p. 19).

1954 ), pp. 3-4 (ACRL Monograph 20, p. 19). 19 Letter dated October 1, 1956 to authors of ACR
Monograph No. 20. (ACRL Monograph 20, p. 20).

20 American Council on Pharmaceutical Education, Accreditation Manual (Formerly Accreditation Policy and Procedure): Policy, Procedure and Standards to be Used as the Basis for Accreditation of Colleges of Pharmacy (5th ed; Chicago: The Council, 1952), pp. 9, 23. (ACRL Monograph 20, pp. 20-21). through its secretary ${ }^{21}$ also expresses the conviction that standards and principles should be stated in general terms and should not include "rigid specifications" on such matters as library holdings. The accreditation requirements ${ }^{22}$ of this organization recognize certain fundamental bases, such as that the library "should be administered by a professionally trained and experienced librarian."

The standards formulated for ALA by its Board of Education for Librarianship $^{23}$ list some of the characteristics the staff members of the library school library should have and some of the library activities in which they should engage. It is clear that the standards and the interpretative statement ${ }^{24}$ consider it highly desirable that the library staff and the faculty cooperate and that library staff members have access to, or be members of, faculty committees. However, matters of status are not directly discussed. It should also be noted that the ALA standards assume that the institution of which the library school is a part has been approved beforehand by the respective regional accrediting association which may have imposed additional personnel requirements.

The Manual of Accrediting of the American Optometric Association 25 mentions library personnel only briefly, and mainly in terms of services to be rendered by the staff to faculty members and students. The standards require that library expenditures be sufficient to "secure trained personnel."

21 Letter dated September 27, 1956 to authors of ACRL Monograph No. 20 (ACRL Monograph 20, p.

21). American Dental Association. Council on Dental Education. Requirements for the Approval of a Dental School (Chicago: The Association, 1955), p. 8. (ACRL Monograph 20, p. 21).

28 American Library Association, Board of Education for Librarianship, "Standards for Accreditation," ALA Bulletin, XLVI (1952), 48-49. (ACRL Monograph 20, pp. 21-22).

24 American Library Association. Board of Educa24 American Library Association. Board of Educa-
tion for Librarianship. Statement of Interpretation to Accompany Standards for Accreditation. Adopted by the ALA Council, July 13, 1951 (Chicago: ALA, 1952), pp. 20-22. (ACRL Monograph 20, pp. 22-24). 20 American Optometric Association. Council on Ed ucation and Professional Guidance. Manual of Accredit ing (4th ed, Minneapolis: The Association, 1953), pp. 9, 29-30. (ÁCRL Monograph 20, pp. 24-25). 
The executive officer of the Education and Training Board of the American Psychological Association notes ${ }^{26}$ that the association never has prepared a statement of standards. Moreover, the association evaluates only doctoral programs in clinical or counseling psychology. On the occasion of such accreditation visits the following question relating to the library is asked: "Comment on adequacy of your library facilities and its availability to graduate students (No. of annual accessions, amount spent yearly, etc.)." 27 The competency of personnel and its status within the school are not specifically listed as items to be investigated.

The American Public Health Association has established Criteria for Institutions to be Accredited for the Degree of Master of Public Health (Diploma of Public Health in Canada) and for the Degree of Doctor of Public Health. ${ }^{28}$ Criterion 6, which is devoted to the library, recognizes that library facilities are essential and that book and periodical resources should be provided in certain areas pertinent to the curriculum. Criterion 6 is silent with regard to the staff.

The American Veterinary Medical Association expresses great interest in maintaining high standards in the library area. The secretary of its council emphasizes $^{29}$ that the future will bring more specific provisions than those which now govern accreditation. At present it is merely expected that the veterinary medical school library be adminis-

28 Letter dated September 18, 1956 to authors of ACRL Monograph No. 20 (ACRL Monograph 20, p.

26). American Psychological Association. Form III: Course Offerings and General Facilities (Worm $I I T$ : D.C.: The Association, n.d.), p. 7. (ACRL Monograph 20, p. 26).

on Promerican Public Health Association. Committee on Professional Education. Criteria for Institutions to Health (Diploma of Public Health in Canada) and for the Degree of Doctor of Public Health (New York: the Degree of Doctor of Public Health (New York: p. 26$)$.

29 Letter dated October 3, 1956 to authors of ACRL Monograph No. 20 (ACRL Monograph 20, p. 26). tered by "a professionally trained or experienced librarian."

The standards for libraries of the Council on Social Work Education ${ }^{30}$ are vague in defining the criteria relating to the staff. "Competent library staff should be available" is the only admonition given the schools.

The Engineers Council for Professional Development has, as stated by the chairman of the Engineering and Accreditation Committee, ${ }^{31}$ "carefully avoided any definite standards with respect to any part of its criteria for accreditation of undergraduate engineering curricula." It relies rather on an over-all appraisal successively undertaken by three groups of "respected members of the profession." In this overall evaluative process the library is a highly important ingredient. It should, as the letter states, "contribute its share to refusal of accreditation." Within the framework of this policy it is understandable that the accrediting teams receive only hints as to the factors to be considered but no definitely circumscribed directives.

In the standards governing the accreditation of medical schools ${ }^{32}$ and in an interpretative letter from the secretary of the Council on Medical Education, ${ }^{33}$ the great variety prevailing among the objectives of the various medical schools is stressed. This variety requires much flexibility in the formulation and application of the standards, as the secretary notes. But, whatever the objectives of the organization, the availability of a "trained librarian" with experience in medical library practice is stipulated.

so Council on Social Work Education. Commission on Accreditation. Manual of Accreditation Standards. (n.p. 1953), sec. 5200-5270. (ACRL Monograph 20, pp. 30-31).

81 Letter, dated October 4, 1956, to authors of ACRL Monograph No, 20 (ACRL' Monograph 20, pp. 31-32). 82 American Medical Association. Council on Medical Association and Hospitals. Essentials of an Acceptable Medical School. (n.p., 1951), sec. v (ACRL Monograph 20 , pp. 32-34).

ss Letter, dated September 27, 1956, to authors of ACRL Monograph No. 20 (ACRL Monograph 20, pp. 32-34).

COLLEGE AND RESEARCH LIBRARIES 


\begin{tabular}{l}
\hline Association \\
\hline $\begin{array}{c}\text { Am. Assn. of Collegiate } \\
\text { Schools of Business }\end{array}$ \\
Am. Bar Assn. \\
Am. Chemical Soc. \\
Am. Council on Ed. for \\
Journalism
\end{tabular}

Am. Council on Pharmaceutical Ed.

Am. Dental Assn.

\section{ALA}

Am. Optometric Assı.

Am. Psychological Assn.

Am. Public Health Assn.

Am. Veterinary Medical Assn.*

Assn. of Am. Law Schools

Council on Social Work Ed.

Engineers' Committee on Professional Development*

Liaison Committee on Medical Ed.

Nat. Architectural Accrediting Board*

Nat. Assn. of Schools of Design*t+

Nat. Assn. of Schools of Music

Nat. Council for Accreditation of Teacher Ed.f

Nat. League for Nursing +

Soc. of Am. Foresters
Library should be in charge of trained library personnel

Library should be administered by a professionally trained and experienced librarian

In terms of functions performed

Trained personnel

Professionally trained or experienced librarian

Law library experience and/or legal education of librarian

Competent library staff

Services of a good librarian desirable

Trained librarian with experience in medical practice

Professional personnel coverage.

Professional staff
ACCEPTABLE FORMS OF ORGANIZATION OF PROFESSIONAL SCHOOL LIBRARY

Either separate or part of main library

Determined by degree of autonomy granted in administering library

Location in chemistry building preferred

Either separate or section of combined library

Either separate or department of main library

Usually department of main library

Autonomous or part of centralized system

Either housed within central library or in school building

Many variations recognized

Facilities either in general library or as a separate unit

* Indicates practice. No standards published.

$\ddagger$ Indicates that regional accreditation standards are accepted. 
The National Architectural Accrediting Board, according to statements contained in letters from the secretary of the board, ${ }^{34}$ limits its evaluation to libraries which are "autonomous within the individual architectural schools which it visits." Schools are urged to experiment, and therefore rigid standards are avoided at all cost. Each school is to be viewed within the framework of its own objectives. Seating capacity and expenditures for library materials are the only two items specifically listed as worthy of the visitors' attention.

According to a letter from the chairman of the Committee on Standards of the National Association of Schools of Design, ${ }^{35}$ this association relies completely on the various regional accrediting agencies. Therefore it has not issued any standards of its own. However, this association underlines the significant role of the library in the educational program and, among other items, it stresses the need for "professional personnel coverage."

The National Association of Schools of Music, according to its secretary, ${ }^{36}$ has shown a continuing concern with the music libraries of its member institutions. The attention has been focused solely on holdings, and for this reason the association has published lists of books which are expected to be held by music schools applying for membership in the association.

The Standards of the National Council for Accreditation of Teacher Education consider adequate facilities for an education library as essential. ${ }^{37}$ The council's particular concern is with the provision of materials of instruction

34 Letters dated September 29, 1956 and January 21. 1957 to authors of ACRL Monograph No. 20 (ACRL Monograph 20 , pp. 34,35 ).

35 Letter dated December 5,1956 to authors of ACRL Monograph No. 20 (ACRL Monograph 20, p. 35) ${ }_{38}$ Letter dated October 3, 1956 to authors of ACRL Monograph No. 20 (ACRL Monograph 20, pp. 35-36). cation. Standards and Guides for Accreditation of Institutions and Programs for Teacher Education. (n.p. stitutions and Programs for Teacher Education. (n.p.
1956 ), standard VII. (ACRL Monograph 20 p. 36). which are indispensable to teacher training. It relies, however, on the regional accrediting associations for the evaluation of all other library matters, including personnel. ${ }^{38}$

The National League for Nursing does not deem it necessary to adopt specific standards. The league accepts the over-all standards of the respective regional associations as they are applied to the institutions of which schools of nursing are integral parts. ${ }^{39}$

The Society of American Foresters offers criteria for evaluation which are intended to serve only as general guides. ${ }^{40}$ "Professional staff" is one of the several items to be considered by the visiting committees. Like the other items, it is to be checked as "Adequate," "Barely Adequate," or "Inadequate." Since "professional staff" is not further defined, the judgment of adequacy must be completely left to the discretion of the evaluators.

\section{Conclusions}

This analysis has shown that the standards of all regional accrediting associations except those of the Northwest Association specify faculty status for the head librarian. Only the Southern Association insists that the whole professional staff be included in the faculty, and the Western College Association extends faculty status at least to the chief librarian and to the professional heads of the library departments.

Turning to the professional associations, we find that only one, the Association of American Law Schools, expresses clearly a preference for faculty status of the head librarian. None of the stand-

38 Letter of director of Council dated October 1, 1956 to authors of ACRL Monograph No. 20 (ACRL Monograph 20 , p. 36).

${ }_{30}$ Letter of assistant director of Department of Baccalaureate and Higher Degree Programs dated October 31, 1956 to authors of ACRL Monograph No.

20 (ACRL Monograph 20, p. 37). ing Schools of Forestry (Washington, D.C.: The Society, 1955), pp. 6, 10, 11. (ACRL Monograph 20, p. 37).

COLLEGE ANDRESEARCH LIBRARIES 
ards of the other professional associations specifically require faculty membership for either the head librarian or for any other member of the library's staff.

It should be kept in mind that the professional associations are primarily concerned with the holdings of the professional school library or the special collection. In several of the standards of the professional associations the connection with the central library of the university or college is noted. If the professional library or collection is under the general direction of the central library the general library personnel policies are expected to prevail. In a few instances, professional associations rely on evaluation of the whole institution, including the library, by regional accrediting associations. In these cases, silence with regard to personnel should therefore not be interpreted as lack of interest, but as a commendable endeavor to avoid duplication of effort.

Professional associations which do not rely on library inspection and library evaluation by regional associations must be especially watchful in the area of personnel. If they wish to insure expert interpretation of the library's resources and full integration of the library with the total educational process, then they should guarantee through proper provisions in their standards that librarians have background and training comparable to that of the teaching faculty.
So far over half of the colleges and universities in the country have given proper academic recognition to their professional library staffs, according to the recently published "Status of College and University Librarians." 41 This report adduces most compelling arguments in favor of academic status with corresponding privileges and obligations. It proposes a concept which ranges from full faculty status with academic rank and titles to membership in the academic community with equivalent and corresponding ranks.

On account of its adaptability to differing local situations the status report would be exceptionally useful to the various accrediting agencies as a guide. It is therefore hoped that the agencies will make the arguments of the report their own and transform them into rules to be applied when accrediting institutions of higher learning. Academic recognition for all professional librarians will then be speedily attained.

41 Prepared by the Committee on Academic Status of ACRL's University Libraries Section; adopted by the Section at the 1959 Washington Conference; and subsequently approved for the ALA by the ACRL Board of Directors. CRL XX (1959), 399-400.

Also significant in this connection are the new "ALA Standards For College Libraries," prepared by the Standards For College Libraries, prepared by the ACRL Committee on Standards; adopted by the ACRL subsequently approved by the ALA Council at the 1959 Washington Conference. The standards, designed to provide a guide for the evaluation of libraries in American colleges and universities which place their major emphasis on four-year undergraduate instruction, major emphasis on four-year undergraduate instruction, unequivocally insist that the professional librarians have ing staff." CRL $X X$ (1959), 274-80. See esp. p. 274 and p. 276.

INFORMATION, PLEASE: Dr. Ralph E. Ellsworth, director of the University of Colorado Library, Boulder, is writing a book on college and university library buildings. One of the aspects of library building planning which Dr. Ellsworth feels is most in need of critical analysis, and one which he hopes to treat in some length in his forthcoming book, is the library building program. To aid him in this analysis he would be grateful if librarians in charge of college and university library buildings that have been erected since World War II would send him a copy of the written program that was compiled during the planning stages. 